\title{
ADENOSINE THIAMINE TRIPHOSPHATE AND ADENOSINE THIAMINE TRIPHOSPHATE HYDROLASE ACTIVITY IN ANIMAL TISSUES
}

\author{
A. F. MAKARCHIKOV ${ }^{1,2}$, T. V. SAROKA ${ }^{3}$, T. G. KUDYRKA ${ }^{1,2}$, I. K. KOLAS ${ }^{1,2}$, \\ T. A. LUCHKO' , I. M. RUSINA ${ }^{1,2}$, V. A. GURINOVICH ${ }^{2}$ \\ ${ }^{1}$ Grodno State Agrarian University, Belarus; \\ ${ }^{2}$ Institute of Biochemistry of Biologically Active Compounds, \\ National Academy of Sciences of Belarus; \\ ${ }^{3}$ Yanka Kupala State University of Grodno, Belarus; \\ e-mail:a_makarchikov@yahoo.com
}

\begin{abstract}
Adenosine thiamine triphosphate (AThTP), a vitamin $B_{1}$ containing nucleotide with unknown biochemical role, was found previously to be present in various biological objects including bacteria, yeast, some human, rat and mouse tissues, as well as plant roots. In this study we quantify AThTP in mouse, rat, bovine and chicken tissues. We also show that in animal tissues the hydrolysis of AThTP is catalyzed by a membranebound enzyme seemingly of microsomal origin as established for rat liver, which exhibits an alkaline $p H$ optimum of 8.0-8.5 and requires no $\mathrm{Mg}^{2+}$ ions for activity. In liver homogenates, AThTP hydrolase obeys Michaelis-Menten kinetics with apparent $K_{m}$ values of $84.4 \pm 9.4$ and $54.6 \pm 13.1 \mu M$ as estimated from the Hanes plots for rat and chicken enzymes, respectively. The hydrolysis of AThTP has been found to occur in all samples examined from rat, chicken and bovine tissues, with liver and kidney being the most abundant in enzyme activity. In rat liver, the activity of AThTP hydrolase depends on the age of animals.
\end{abstract}

Ke y w ord s: vitamin $B_{1}$, adenosine thiamine triphosphate, adenosine thiamine triphosphate hydrolase, animal tissues.

$\mathrm{V}$ itamin $\mathrm{B}_{1}$ in the form of thiamine diphosphate (ThDP) plays an important role in the vital activity of the cell, fulfilling catalytic functions. Currently, more than 30 ThDP-dependent enzymes have been known, five of them are encoded by animal genomes. Pyruvate dehydrogenase (EC 1.2.4.1), oxoglutarate dehydrogenase (EC 1.2.4.2) as well as 3-methyl-2-oxobutanoat dehydrogenase (EC 1.2.4.4) are components of mitochondrial dehydrogenase complexes involved in carbohydrate, amino acid and energy metabolism [1]. The metabolic role of transketolase (EC 2.2.1.1), which catalyzes a two-carbon moiety transfer from ketose to aldose sugars, is to provide a reversible link between glycolysis and pentose phosphate pathway [2]. One more ThDP-dependent enzyme, 2-hydroxyacilCoA lyase (EC 4.1.2.n2), is involved in the peroxisomal metabolism of 3-methyl-branched fatty acids and 2-hydroxy straight-chain fatty acids [3]. Alongside with ThDP, small amounts of thiamine, thiamine monophosphate (ThMP) and thiamine triphosphate (ThTP) are also present in animal tissues; the biological significance of these phosphate derivatives have not been yet established [4].

In 2007, a new nucleotide, adenosine thiamine triphosphate (AThTP), was revealed and identified in bacteria, some plant and animal tissues [5]. Though biochemical role for AThTP has not been ascertained to date, experiments with $E$. coli may indicate this compound to be involved in the molecular mechanisms of short-term adaptation through signaling/ regulatory function. For instance, the concentration of AThTP, normally contained in a bacterial cell only in tiny amounts, was found to increase many times under carbon starvation. A similar picture was observed when the energy metabolism of the cell

(C) 2018 Makarchikov A. F. et al. This is an open-access article distributed under the terms of the Creative Commons Attribution License, which permits unrestricted use, distribution, and reproduction in any medium, provided the original author and source are credited. 
was disturbed with uncoupling agents as well as the inhibitors of glycolysis and respiratory chain [6]. In accordance to Tanaka et al. [7], in vitro AThTP inhibits the activity of poly(ADP-ribose) polymerase 1 , a nuclear enzyme playing the central role in cellular responses to various stress factors.

At present, the enzymes involved in AThTP metabolism are not identified. It is only known that the synthesis of AThTP in E. coli is catalyzed from ThDP and ADP(ATP) by a soluble $\mathrm{Mg}^{2+}$-dependent protein with molecular mass of $355 \mathrm{kDa}$ [8]. An enzyme capable of AThTP hydrolyzing was also found to be localized in the bacterial membrane [5].

This work is aimed at determining AThTP and characterizing some properties of the enzyme which catalyzes the hydrolysis of AThTP in animal tissues.

\section{Materials and Methods}

Alcohol dehydrogenase (ADH, EC 1.1.1.1), AMP, ThDP, NAD ${ }^{+}$, NADH, Tris base, trichloroacetic acid (TCA), bovine serum albumin, glucose6-phosphate, SP-Sephadex C-25 and DEAE-Sephadex A-25 were purchased from Sigma-Aldrich (St. Louis, Mo., USA), pyridine, N,N'-dicyclohexylcarbodiimide (DCC) and tetra-n-butylammonium hydrogen sulfate were from Acros Organics (New Jersey, USA), tetrahydrofuran was from Fisher Scientific (Loughborough, UK), all other chemicals were of analytical grade from Reakhim (Moscow, Russia).

Apoenzyme of pyruvate decarboxylase (PDC, EC 4.1.1.1) was prepared from brewer's yeast Saccharomyces carlsbergensis as described by Chernikevich et al. [9].

AThTP was synthesized by condensing ThDP and AMP in pyridine in the presence of DCC [5]. Briefly, the procedure of AThTP preparation was as follows. The reaction mixture containing $1.38 \mathrm{mg} /$ $\mathrm{ml}$ of ThDP, $1.26 \mathrm{mg} / \mathrm{ml}$ of AMP and $86.2 \mathrm{mg} / \mathrm{ml}$ of DCC was incubated for $3 \mathrm{~h}$ at $50{ }^{\circ} \mathrm{C}$, after that 3 volumes of absolute ethanol were added. To purify the product the precipitate formed was dissolved in $5 \mathrm{mM}$ sodium acetate, $\mathrm{pH} 3.8$, and passed through a column of SP-Sephadex C-25 in the same buffer. The fractions containing AThTP were combined and applied to a DEAE-Sephadex A-25 column equilibrated with $10 \mathrm{mM}$ Tris-HCl, $\mathrm{pH}$ 7.2. The elution was carried out with a linear gradient of increasing $\mathrm{NaCl}$ concentration from 0 to $0.3 \mathrm{M}$. Then the AThTP fractions were concentrated by evaporation and precipitated with absolute ethanol. Finally, the precipitate was dissolved in $5 \mathrm{mM}$ sodium acetate buffer, $\mathrm{pH} 3.8$, and chromatographed repeatedly on a SP-Sephadex C-25 column. The purity of the preparation obtained was $99 \%$.

Male Wistar rats (180-190 g) and mice (23$25 \mathrm{~g}$ ) were from the institutional animal quarters. All experiments were performed in accordance with Directive 2010/63/EU of the European Parliament and of the Council on the protection of animals used for scientific purposes. The samples of bovine tissues were obtained from the local slaughterhouse. Chicken tissue samples were from 43-day old freerange Leghorn chicks grown on a courtyard. After killing animals the tissues were immediately frozen in liquid nitrogen and stored at $-80^{\circ} \mathrm{C}$ until use.

For enzyme assays, frozen tissues were homogenized in 5 volumes of $50 \mathrm{mM}$ Tris- $\mathrm{HCl}$ buffer, $\mathrm{pH} 7.5$, containing $0.15 \mathrm{M} \mathrm{KCl}$ and $0.2 \mathrm{mM}$ EDTA, in a glass/glass Potter-Elvehjem homogenizer at $4{ }^{\circ} \mathrm{C}$. To prepare extracts the homogenates were centrifuged at $20000 \mathrm{~g}$ for $60 \mathrm{~min}$.

All operations on isolating subcellular fractions from rat liver were performed at $0-4{ }^{\circ} \mathrm{C}$. A sample of fresh tissue was forced through a $1 \mathrm{~mm}$ pore press and homogenized by 10 strokes in a teflon/glass Potter-Elvehjem device at $600 \mathrm{rpm}$ in 10 volumes of $10 \mathrm{mM}$ Tris- $\mathrm{HCl}$ buffer, $\mathrm{pH} 7.4$, containing $0.25 \mathrm{M}$ sucrose, $0.5 \mathrm{mM}$ EDTA and $0.1 \mathrm{mM} \mathrm{MgCl}_{2}$. The homogenate was filtered through four layers of wet gauze and centrifuged at $600 \mathrm{~g}$ for $10 \mathrm{~min}$. The pellet was suspended in 10 volumes of the initial buffer and centrifuged (600 g, $10 \mathrm{~min}$ ) again to yield a crude nuclear fraction. To prepare mitochondria the postnuclear supernatants were combined and subjected to further centrifugation at $12000 \mathrm{~g}$ for $10 \mathrm{~min}$. The particles were washed once with the same medium giving a crude mitochondrial fraction. Then the post-mitochondrial supernatants were pooled and adjusted to $\mathrm{pH} 7.5$ with $0.5 \mathrm{M}$ Tris-HCl, $\mathrm{pH}$ 8.0, followed by adding $\mathrm{CaCl}_{2}$ to a final concentration of $15 \mathrm{mM}$. After 2 hours, the suspension was centrifuged (14 $000 \mathrm{~g}, 10 \mathrm{~min}$ ) to obtain microsomal and cytosol fractions. Finally, the particular fractions were suspended in $50 \mathrm{mM}$ Tris- $\mathrm{HCl}$ buffer, $\mathrm{pH}$ 7.3, containing $0.15 \mathrm{M} \mathrm{KCl}, 0.2 \mathrm{mM}$ EDTA, and frozen at $-80^{\circ} \mathrm{C}$ along with the cytosol for storage.

The activities of marker enzymes (lactate dehydrogenase (LDH, EC 1.1.1.27), succinate dehydrogenase (SDH, EC 1.3.5.1) and glucose-6phosphatase (G6Pase, EC 3.1.3.9)) as well as the quantity of DNA in the subcellular fractions were assayed by conventional methods. 
The standard mixture for AThTP hydrolase activity determination contained $50 \mathrm{mM}$ sodium phosphate buffer, $\mathrm{pH}$ 8.0, $0.05 \mathrm{mM}$ substrate and an aliquot of enzyme solution (1-10 microliters of tissue homogenate) in a total volume of $0.1 \mathrm{ml}$. Kinetic experiments required some alterations in the assay with respect to $\mathrm{pH}$ or substrate concentration; it is indicated as necessary. The reaction was carried out for 10-30 min at $37^{\circ} \mathrm{C}$, depending on tissue and homogenate amount, to measure the initial velocity. Linearity in product accumulation was observed at given time intervals. After the reaction was stopped by boiling for $1 \mathrm{~min}$, the mixture was diluted fivefold with $20 \mathrm{mM}$ sodium phosphate buffer, $\mathrm{pH} 6.8$, and centrifuged (3 $000 \mathrm{~g}, 10 \mathrm{~min}$ ) to remove a protein precipitate. The amount of ThDP produced was measured by enzymatic method [9]. For this purpose, a $0.05-\mathrm{ml}$ aliquot of the supernatant was incubated for $30 \mathrm{~min}$ at $25{ }^{\circ} \mathrm{C}$ with yeast apoPDC to reconstitute an active enzyme. The activity of holoPDC was then determined on decreasing NADH adsorption at $340 \mathrm{~nm}$ in a coupled reaction with ADH. To quantify ThDP a calibration graph was built using a chromatographically pure standard.

A unit of enzyme activity (U) was defined as the amount that catalyzes the formation of $1 \mu$ mole of ThDP in one minute.

The content of AThTP in animal tissues was evaluated by ion-pair reversed-phase HPLC [10]. Frozen tissue samples were homogenized in 5 volumes of $12 \%$ TCA in a glass/glass Potter-Elvehjem homogenizer at $0-4{ }^{\circ} \mathrm{C}$ and centrifuged (20 $000 \mathrm{~g}$, $\left.15 \mathrm{~min}, 4^{\circ} \mathrm{C}\right)$. To extract the acid an aliquot $(0.2 \mathrm{ml})$ of the supernatant was treated with diethyl ester ( 3 times $0.6 \mathrm{ml}$ each). Then the solution was placed into Agilent 1200 autosampler where an aliquot of $13 \mu 1$ was mixed with $8 \mu 1$ of $4.3 \mathrm{mM} \mathrm{K}_{3}\left[\mathrm{Fe}(\mathrm{CN})_{6}\right]$ in $15 \% \mathrm{KOH}$ to produce fluorescent thiochrome derivatives of thiamine compounds and injected into the chromatographic system. The separation was performed at a flow rate of $0.5 \mathrm{ml} / \mathrm{min}$ on a PRP-1 column (4.1×150 mm, Hamilton Co, Reno, NV, USA), equipped with a PRP-X100 guard cartridge, in 50

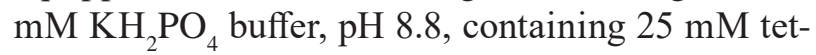
ra-n-butylammonium hydrogen sulfate and $4 \%$ tetrahydrofuran. Thiochrome derivatives were quantified using a fluorometric detector $\left(\lambda_{\mathrm{ex}}=365 \mathrm{~nm}\right.$, $\lambda_{\text {em }}=433 \mathrm{~nm}$ ).

The identification of fluorescing products of AThTP hydrolase was done with HPLC as described above after the reaction was stopped by addition of $0.1 \mathrm{ml}$ of $12 \%$ TCA and the mixture was centrifuged
(12 $000 \mathrm{~g}, 10 \mathrm{~min}, 4^{\circ} \mathrm{C}$ ) to remove precipitated proteins.

Protein was determined by the method of Peterson [11] with bovine serum albumin as a standard. Statistical calculations were made using a GraphPadPrism 5.0 program.

\section{Results and Discussion}

Occurrence and quantification of AThTP in bovine and chicken tissues. AThTP was originally discovered and identified in E. coli where it is accumulated in high amounts during carbon starvation [5]. This nucleotide seems to be also present in yeast, plant roots and some human, rat and mouse tissues, based on chromatographic peaks appearance corresponding to the retention time $\left(t_{\mathrm{R}}\right)$ of an authentic standard $[5,12,13]$. In this work we studied by HPLC the occurrence of AThTP in tissues of two species of farm animals, namely the cattle (Bos taurus taurus) and the chicken (Gallus gallus). To compare with literature data the content of AThTP in some tissues of rats (Rattus norvegicus) and mice (Mus musculus) was determined as well.

Judging by the chromatographic peaks, the biosynthesis of AThTP takes place in all bovine tissues examined. However, we were not able to detect this compound in any sample of chicken liver or kidney, much like it was reported previously [12] for another bird species, the quail (Coturnix coturnix). It is to be noted that AThTP was also not found in human liver biopsies [13]. On the other hand, small but clearly distinguishable peaks with $t_{\mathrm{R}}$ corresponding to AThTP could be observed on chromatograms of extracts from chicken heart, brain and skeletal muscle, while no AThTP was detectable in any quail tissue [12]. Fig. 1 shows examples of chromatograms for chicken brain and breast muscle as well as mammalian livers. The results obtained on AThTP quantification in animal tissues are summarized in Table 1.

According to our data, the concentration of AThTP in rats varies from 3.5 to $89.3 \mathrm{pmol} / \mathrm{g}$ wet tissue, the lung being the most abundant tissue followed by the spleen and liver. In mice, AThTP levels were found to be within the same range (6.4$68.5 \mathrm{pmol} / \mathrm{g}$ wet tissue). As a whole, these data are in a good agreement with the results of studies where the content of AThTP was expressed per $1 \mathrm{mg}$ of protein [5, 12], especially in view of incomplete alkaline extraction of proteins from TCA precipitates. As can be seen from Table 1, among the bovine tissues examined the highest AThTP concentration, on 

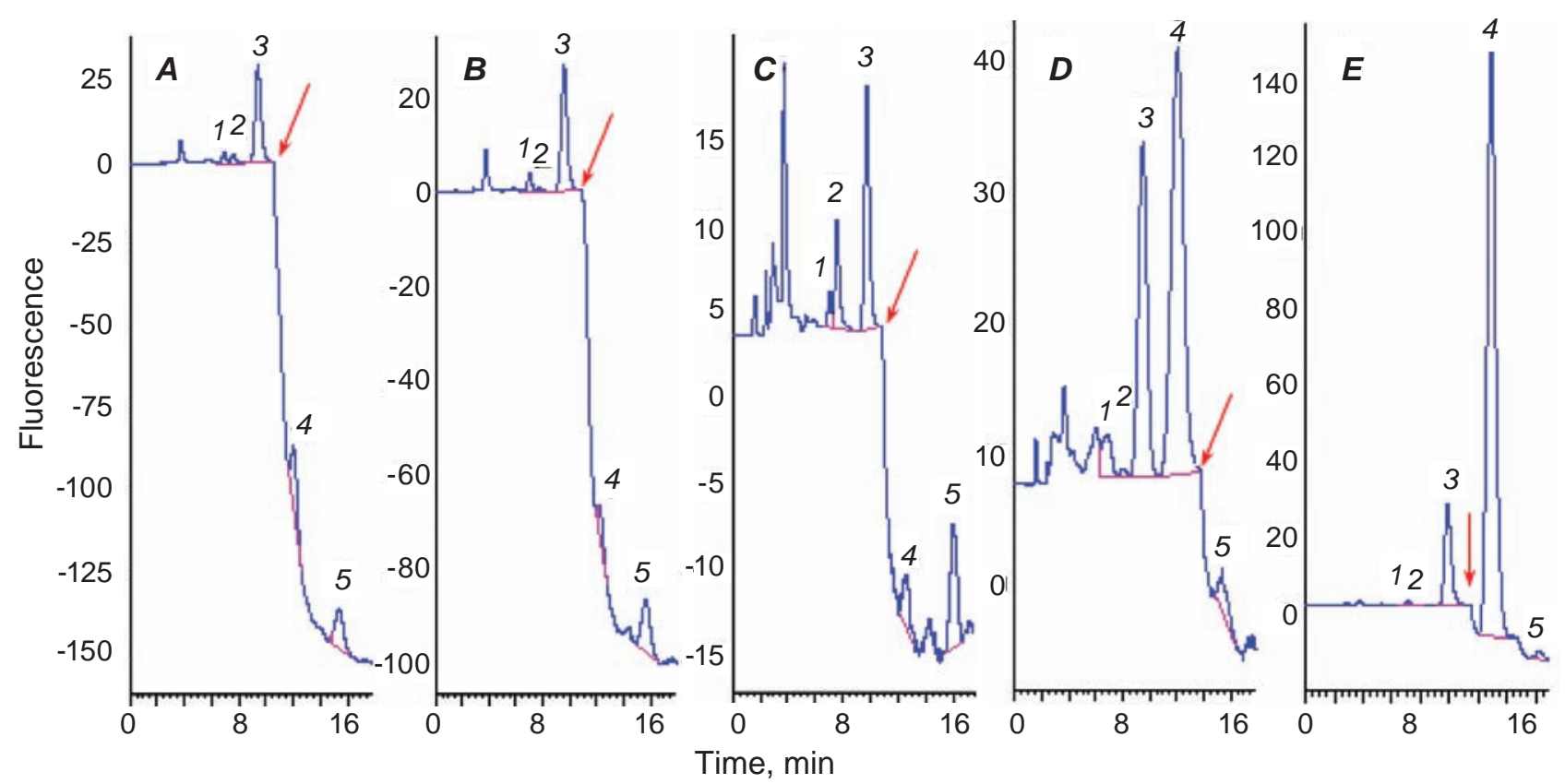

Fig. 1. Occurrence of AThTP in several animal species: rat liver $(\boldsymbol{A})$, mouse liver $(\boldsymbol{B})$, bovine liver $(\boldsymbol{C})$, chicken muscle (D), chicken brain (E). The arrows indicate the moment of the detector switching to the highest sensitivity. 1, ThMP; 2, thiamine; 3, ThDP; 4, ThTP; 5, AThTP. Thiamine derivatives were determined by HPLC as described in Materials and Methods

Ta ble 1. AThTP content in animal tissues (pmol/g wet tissue)

\begin{tabular}{l|c|c|c|c|c|c|c}
\hline \multicolumn{1}{c|}{ Species } & Liver & Heart & Brain & Kidney & Lung & Muscle & Spleen \\
\hline Bovine $^{1}$ & $32.0 \pm 26.8$ & $191.0 \pm 117.8$ & $10.2 \pm 6.6$ & $27.3 \pm 23.6^{6}$ & $15.9 \pm 0.1^{6}$ & $4.4 \pm 2.0^{4}$ & $3.0 \pm 0.2^{6}$ \\
Chicken $^{1}$ & n.d. & $2.2 \pm 0.9$ & $3.8 \pm 0.5$ & n.d. & n.d. & $11.7 \pm 3.2^{5}$ & n.d. \\
Rat $^{1}$ & $33.9 \pm 11.8$ & $9.3 \pm 1.0$ & $3.5 \pm 3.0$ & $14.3 \pm 3.7$ & $89.3 \pm 11.4$ & $6.7 \pm 2.0^{3,6}$ & $36.7 \pm 3.5$ \\
Mouse $^{2}$ & $15.9 \pm 2.2$ & $68.5 \pm 5.3$ & $6.4 \pm 1.1$ & n.a. & n.a. & n.a. & n.a. \\
\hline
\end{tabular}

${ }^{1}$ Number of animals, $n=3$; ${ }^{2}$ number of animals, $n=9$; ${ }^{3}$ thigh muscles; ${ }^{4}$ upper part of neck; ${ }^{5}$ breast muscle (m. pectoralis); ${ }^{6}$ found in 2 samples; Mean \pm SD; n.d., not detected; n.a., not analyzed

the average $191.0 \mathrm{pmol} / \mathrm{g}$ wet tissue, was revealed in the heart. Much smaller quantities of this compound were detected in other bovine tissues, the significant variability of values being observed. For instance, the livers of two animals contained 12.4 and 21.0 pmol of AThTP per $1 \mathrm{~g}$ of wet tissue, while it was found $62.5 \mathrm{pmol} / \mathrm{g}$ in the third sample. Moreover, the detectable amounts of AThTP were only in every two of three bovine kidneys, lungs and spleens. One may speculate that such significant intraspecies variations, at least partially, are due to the individual sensitivity of animals to pre-slaughter stress. Indeed, in bacteria, the level of AThTP has been found to depend strongly on physiological conditions $[5,6]$. Another reason could be a tissue structural differentiation, since the weight of a sample (100-200 mg) to be taken pointwise for analysis is incompatible with the weight of the whole tissue. Interestingly, in chicken, AThTP was only detectable in excitable tissues, namely in the brain, heart and skeletal muscle.

Alongside with literature data, our results allow concluding that AThTP concentrations, which could be measured in various eukaryotic organisms, are the values of the same order of magnitude. So, in particular, the amount of AThTP, sporadically detected in human biopsies, was reported to vary from 0.05 to $1.5 \mathrm{pmol} / \mathrm{mg}$ protein [13]. Similar values have also been obtained for yeast ( $0.23 \mathrm{pmol} / \mathrm{mg}$ protein) and plant roots (14-33 pmol/g wet tissue) [5]. At the same time, it should be noted that there is no general pattern in the distribution of AThTP in mammalian tissues. For example, in rats, unlike bovine tis- 
sues, the lung was found to be the highest in AThTP content $(89.3 \pm 11.4 \mathrm{pmol} / \mathrm{g}$ wet tissue), whereas the level of this substance in rodent heart was only $9.3 \pm 1.0 \mathrm{pmol} / \mathrm{g}$ wet tissue (Table 1 ). Thus, the data available indicate the existence of interspecies features as regards to AThTP content in mammalian tissues. It is not clear yet whether these features reflect the physiology of species or they are to be attributed to some external factors or technical reasons. Further studies concerning AThTP distribution and quantification in living organisms might be a step on the way of elucidating its biochemical functions.

Identification of fluorescent products of AThTP hydrolase. Commonly, the quantitative determination of enzyme activity relies on the measurement of initial reaction rates, with either the disappearance of a substrate or increasing a product concentration being traced. Since the initial reaction rate can usually be measured only in the interval of time until the conversion of substrate reaches $20 \%$ of the maximum possible, in view of measurements precision it is preferably to determine product concentrations if an appropriate analytical method is available.

It was shown earlier that at $\mathrm{pH} 7.2$ the cleavage of AThTP in E. coli is catalyzed by a membranebound enzyme, the fluorescent products of the reaction being ThDP and ThMP. The appearance of the last was supposed to be due to ThDP hydrolysis by endogenous enzymes, which has also to be responsible for the degradation of a nucleotide product of AThTP hydrolase reaction [5]. In such a case, when alongside with the enzyme under study the system contains some other proteins capable of further transformation of the reaction products, the only way to determine the activity of this enzyme is to trace the disappearance of its substrate. If AThTP hydrolase is to be assayed with this approach, the separation of constituents of the final reaction mixture should be performed. Indeed, the fluorescence of thiochrome derivative of AThTP is essentially undistinguishable qualitatively from thiochrome and thiochrome phosphates [12]. As to the absorbance spectrum of AThTP, it overlaps with those for thiamine derivatives (unpublished data). In principle, the problem of separation and quantification of thiamine compounds could be resolved using HPLC [5]. On the other hand, there is a possibility to determine AThTP hydrolase activity without exploiting any separation technics. This implies an enzymatic quantification of ThDP through its biospecific binding to apo form of a ThDP-dependent enzyme, for example, PDC followed by assaying the activity of reconstituted holoprotein. In respect of PDC, the enzyme from yeast Saccharomyces carlsbergensis was successfully used before as an analytical tool in studying thiamine metabolism, including the assays of thiamine pyrophosphokinase (EC 2.7.6.2) and thiamine triphosphatase (EC 2.7.6.2) [14-16]. It is evident that two circumstances should be taken into account restricting the suitability of enzyme detection of ThDP for AThTP hydrolase assay. To begin with, ThDP should be the only thiamine derivative as a reaction product, i.e. no its further conversion occurs by the enzyme. Moreover, the activities of phosphatases, which might be present in tissue extract/homogenate and capable of ThDP hydrolyzing, should be avoided. If the first clause fits, these unwanted activities, in principle, may be excluded (minimized) by composing the reaction medium ( $\mathrm{pH}$, ionic strength, buffer species, addition of specific phosphatase inhibitors). Addressing these issues, we performed a series of experiments to identify fluorescent products in the reaction mixture after AThTP being incubated with aliquots of rat and chicken liver homogenates. The liver was chosen as the object of the study because it seems from literature data $[17,18]$ to have the highest ThDPase activity.

At first, we explored the effect of $\mathrm{Mg}^{2+}$ ions on AThTP hydrolysis in rat liver homogenate at $\mathrm{pH} 8.0$ in two buffer systems, sodium phosphate and TrisHCl. Fig. 2 represents the chromatograms of incubation mixtures in phosphate buffer system after stopping the reaction. As can be seen in Fig. 2, $B$, in the absence of $\mathrm{Mg}^{2+}$ the only reaction product to contain the thiamine moiety was ThDP. The addition of $\mathrm{Mg}^{2+}$ into the incubation medium caused the appearance of small amounts of ThMP (about $0.9 \%$ of ThDP formed) (Fig. 2, C), seemingly, due to ThDP hydrolysis by phosphatases which are present in the liver homogenate. Hitherto, there is no proof for a specific ThDPase to exist in biological objects. Nevertheless, it has been known that mammalian cells express two nucleoside diphosphatases (L-type NDPase and B-type NDPase, EC 3.6.1.6) capable of ThDP hydrolyzing at neutral and alkaline pHs $[19,20]$. Both of them require $\mathrm{Mg}^{2+}$ for activity. This may explain, at least partially, the lack of ThMP in the reaction mixture containing no $\mathrm{Mg}^{2+}$ ions. Besides the NDPases above, ThDP was shown to serve as a substrate for alkaline phosphatase (ALKP, EC 3.1.3.1) [17, 21]. However, ALKP should not con- 
tribute significantly to the further dephosphorylation of ThDP formed in AThTP hydrolyzing, since ThDPase activity of ALKP is $\mathrm{Mg}^{2+}$ independent [21]. On the other hand, the percentage of ThMP in the final reaction mixture without $\mathrm{Mg}^{2+}$ was $7.6 \%$ of the amount of ThDP, if AThTP hydrolase reaction was carried out in Tris- $\mathrm{HCl}$ buffer. In this case, the addition of $\mathrm{Mg}^{2+}$ increased the extent of ThDP hydrolysis to $14.6 \%$ (data not shown). Thus, the factor of great importance preventing ThDP hydrolysis in Na-phosphate buffer system, as might be expected, is the high concentration ( $50 \mathrm{mM}$ ) of phosphate ions which inhibit phosphatase activities. Just like in rats, the chicken liver contains an enzyme catalyzing the hydrolysis of AThTP with the production of ThDP (Fig. 2, D, E). No ThTP was observed to appear in the reaction mixture in either case, excepting as a tiny admixture (less than 1\%) which sometimes may be present in AThTP preparations (Fig. 2, D, E).
The results of measuring the rate of AThTP hydrolysis in rat liver homogenates by HPLC, in both Na-phosphate and Tris-HCl buffer systems in the presence or without $\mathrm{Mg}^{2+}$ ions, are illustrated in Fig. 3. As can be seen from the diagram, $\mathrm{Mg}^{2+}$ had no effect on the reaction rate in either buffer solution, in phosphate buffer the rate of AThTP hydrolysis being 53\% higher than in Tris-HCl. Thus, AThTP hydrolase was proven to be a metal-independent protein. It is not excluded that phosphate ions, exerting an inhibitory effect on liver phosphatases, activate AThTP hydrolase itself, though the enzyme inhibition with Tris-HCl might also be the case.

All the further assays of AThTP hydrolase activity were done on the rate of ThDP formation which was quantified by enzymatic method using apo PDC [9].

Localization of AThTP hydrolase in rat and chicken liver. The compartmentation of metabolism
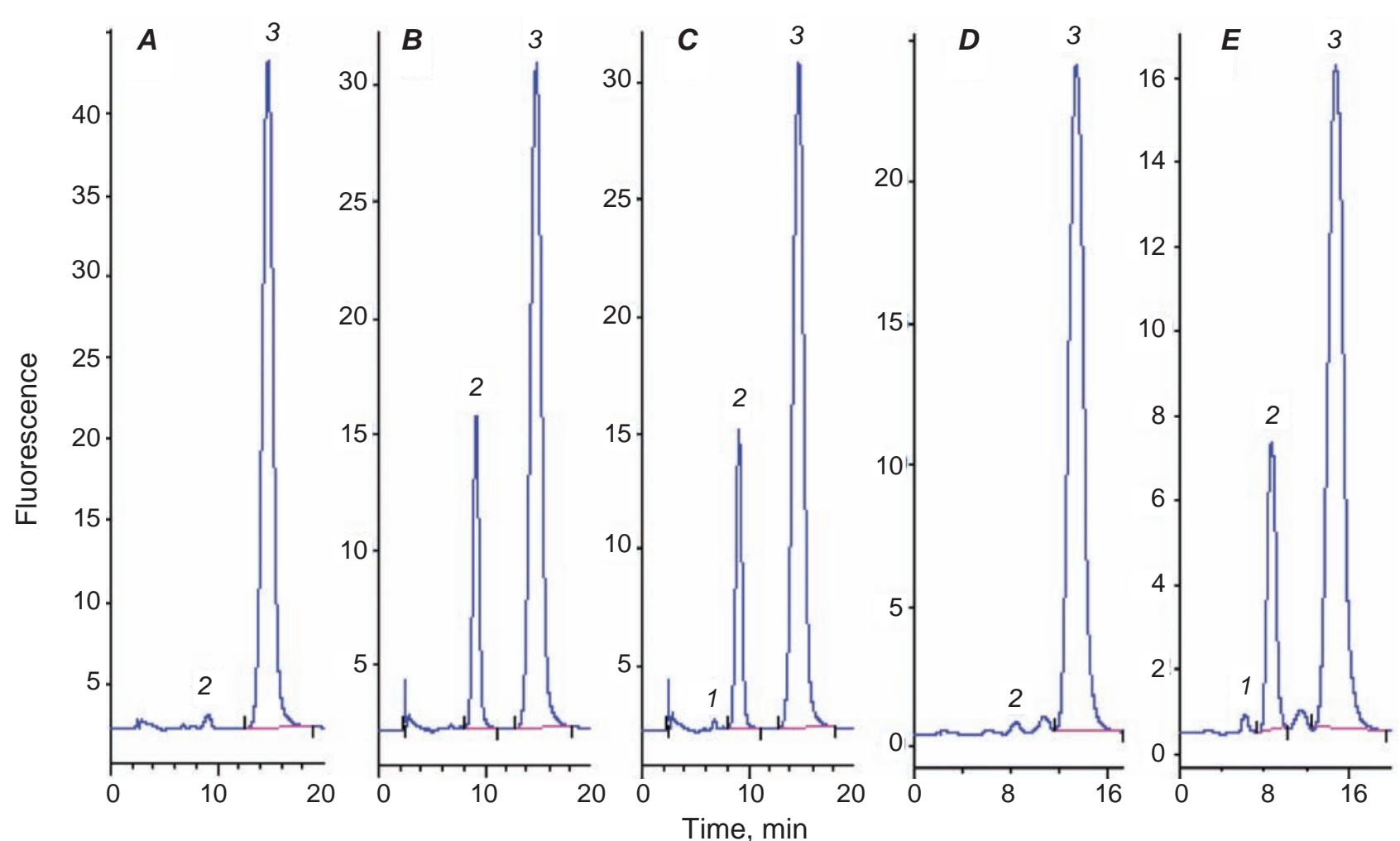

Fig. 2. Chromatographic separation of fluorescent constituents of AThTP hydrolase reaction medium. (A) Composition of the reaction mixture for rat liver homogenate at zero time. (B) Incubation of AThTP with rat liver homogenate was carried out in $50 \mathrm{mM} \mathrm{Na-phosphate} \mathrm{buffer,} \mathrm{pH}$ 8.0, with no $\mathrm{Mg}^{2+}$ added. (C) Incubation of AThTP with rat liver homogenate was carried out in $50 \mathrm{mM}$ Na-phosphate buffer, pH 8.0, with $5 \mathrm{mM}$ $\mathrm{Mg}^{2+}$ added. (D) Composition of the reaction mixture for chicken liver homogenate at zero time. (E) Incubation of AThTP with chicken liver homogenate was carried out in $50 \mathrm{mM}$ Na-phosphate buffer, pH 8.0, without adding $\mathrm{Mg}^{2+}$ ions. 1, ThMP; 2, ThDP; 3, AThTP 
is one of the main organizational principles of cell life which underlies the distribution of all expressed proteins to the places of their functioning. According to some estimates, about $20-30 \%$ of the total number of cellular proteins occurs in the cytosol and liquid phase of organelles; the rest are associated with membranes [22]. Ascertaining the physical state (soluble or particulate) of an enzyme is of importance not only in view of its comprehensive characterization, but also has a practical aspect. For example, the knowledge on an enzyme localization, at least in terms of it being soluble or membranebound, may be essential for its quantification in biological objects, since this determines how the sample should be prepared for analysis (in the form of extract, homogenate or solubilizate). The choice of methods to isolate proteins from tissues for their further purification also depends on localization of those proteins. Fig. 4 depicts the data concerning the distribution of AThTP hydrolase activity between soluble and membrane containing (precipitate obtained by the centrifugation of homogenate for $60 \mathrm{~min}$ at $20000 \mathrm{~g}$ ) fractions of rat and chicken liver. In both cases more than $90 \%$ of the enzyme was precipitated together with the particulate fraction of homogenate. Thus, in animal liver, AThTP hydrolase is a water-insoluble enzyme, much like it

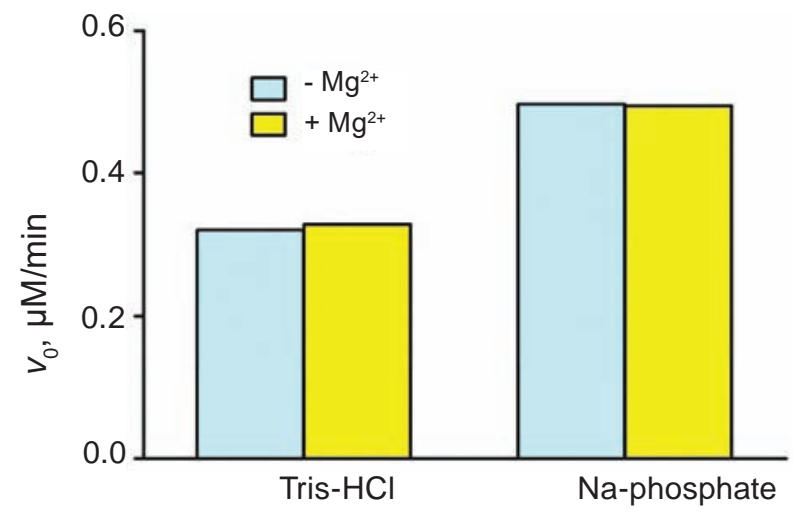

Fig. 3. Effect of $\mathrm{Mg}^{2+}$ (5 $\left.\mathrm{mM}\right)$ on the initial rate of AThTP hydrolysis in rat liver homogenate in $50 \mathrm{mM}$ Tris- $\mathrm{HCl}, \mathrm{pH}$ 8.0, and $50 \mathrm{mM}$ sodium phosphate buffer, $p H$ 8.0. The reaction was carried out for $20 \mathrm{~min}$ at $37^{\circ} \mathrm{C}$ in a volume of $0.1 \mathrm{ml}$ containing $30 \mu \mathrm{g}$ of protein and stopped by adding $0.1 \mathrm{ml}$ of 12\% TCA. After extracting TCA by diethyl ester, the concentrations of thiamine derivatives were measured by HPLC as described in Materials and Methods. Results of a representative experiment are shown

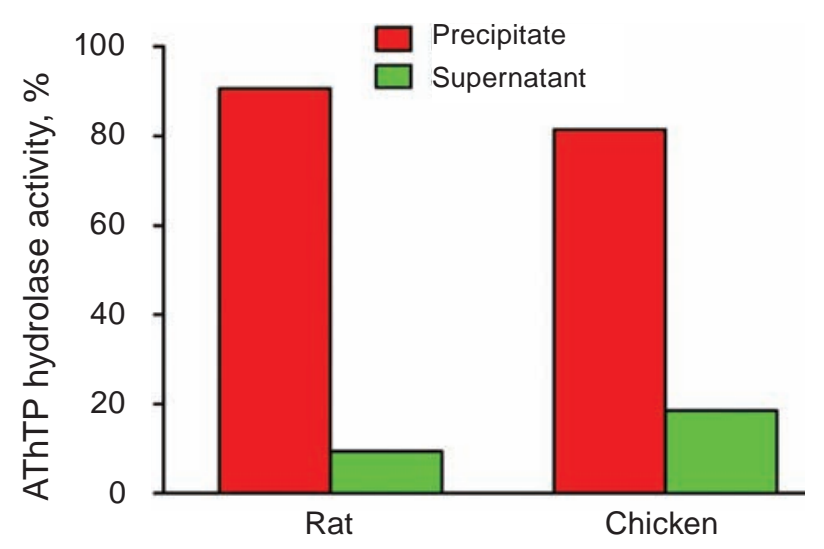

Fig. 4. Distribution of AThTP hydrolase activity between particulate and soluble fractions from rat and chicken liver. The fractions were prepared by the centrifugation of homogenates for 1 hour at $20000 \mathrm{~g}$. The amount of ThDP formed during AThTP hydrolysis at $\mathrm{pH} 8.0$ was measured using PDC as described in Materials and Methods. Results of a representative experiment are shown

was previously reported for the one which catalyzes the hydrolysis of AThTP in E. coli [5].

To study the cellular localization of AThTP hydrolase in more detail the rat liver homogenate was fractionated to produce crude nuclear and mitochondrial fractions, microsomes and the cytosol. Cross-contamination of the fractions was checked by measuring the activities of marker enzymes as well as DNA content. As shown in Table 2, the cytosolic fraction contained small amounts of SDH, G6Pase, DNA and virtually all activity of LDH, indicating the complete disturbance of plasma membrane integrity during homogenization, while intracellular organelles remained unimpaired. Expectedly, the bulk of SDH (75\%) was found in the crude mitochondrial fraction. This fraction also displayed a quite significant G6Pase activity which was probably due to the hydrolysis of glucose-6-phosphate by lysosomal acid phosphatase (EC 3.1.3.2), since lysosomes are known to co-sediment with mitochondria in differential centrifuging. It is also to be noted that mitochondria are irregular in size. They exist, depending on physiological conditions, as distinct small organelles or large fused structures which could sediment together with nuclei contaminating the latter with SDH activity. The presence of appreciable amounts of G6Pase in the nuclear fraction seems to reflect the fact that nuclear envelop and rough endoplasmic reticulum form a continuous membrane system. In 
Ta b le 2. Distribution of AThTP hydrolase activity, marker enzymes and DNA in subcellular fractions from rat liver

\begin{tabular}{l|c|c|c|c|c}
\hline \multirow{2}{*}{ Fraction } & \multirow{2}{*}{ DNA } & \multicolumn{4}{c}{ Enzyme activity, \% } \\
\cline { 3 - 6 } & & LDH & SDH & G6Pase & AThTP hydrolase \\
\hline Nuclei & 81.5 & 0.1 & 15.9 & 27.9 & 30.0 \\
Mitochondria & 13.8 & 0.4 & 75.1 & 18.5 & 22.5 \\
Microsomes & 1.9 & 2.5 & 7.9 & 51.3 & 43.9 \\
Cytosol & 2.8 & 97.0 & 1.1 & 2.3 & 3.6 \\
\hline
\end{tabular}

Results of a representative experiment are shown

view of above, the fractions obtained might be regarded as rather pure. AThTP hydrolase activity was found in all particulate fractions with preferable location in the endoplasmic reticulum (Table 2). Thus, in rat liver, the enzyme is likely to be present in different types of cellular membranes.

Kinetic properties of AThTP hydrolase. Phosphate buffer fits well for AThTP hydrolase assay, but its efficiency is limited by $\mathrm{pH}$ values of 6.2-8.2 $\left(\mathrm{p} K_{\mathrm{a}}=7.2\right)$. Since the activity of AThTP hydrolase depends strongly on a buffer species (Fig. 3), to study the effect of hydrogen ion concentration on the enzyme activity in a wider $\mathrm{pH}$ interval we used basically Tris-maleate buffer system ( $\mathrm{p} K_{\mathrm{a}}$ of maleic acid $=6.24, \mathrm{p} K_{\mathrm{a}}$ of Tris $=8.08$ ). As mentioned above, a further hydrolysis of ThDP produced in AThTP hydrolase reaction in Tris- $\mathrm{HCl}$ buffer was observed, leading to some underestimation of the enzyme activity. However, the extent of such hydrolysis is too small to affect the $\mathrm{pH}$ profile provided that the initial reaction velocity is measured. The dependence of the initial rate of AThTP hydrolysis in rat and chicken liver homogenates on $\mathrm{pH}$ is shown in Fig. 5, A. In both cases the enzyme exhibited the highest activity in a slightly alkaline medium at $\mathrm{pH}$ 8.0-8.5.

The effect of substrate concentration on the initial rate of AThTP hydrolysis by rat (at $\mathrm{pH}$ 8.0) and chicken (at pH 8.5) enzymes is demonstrated in Fig. 5, B, C. Under the test conditions, the reactions followed a classical Michaelis-Menten kinetics giving hyperbolic saturation curves, with apparent $K_{\mathrm{m}}$ of $84.4 \pm 9.4$ and $54.6 \pm 13.1 \mu \mathrm{M}$ (for three experiments) as estimated from the Hanes plots for rat and chicken liver enzymes, correspondingly. When the same data were analyzed by nonlinear regression fit, the values of $K_{\mathrm{m}}$ were calculated to be $63.1 \pm 10.1$ $\mu \mathrm{M}$ (for rat) and $43.0 \pm 17.8 \mu \mathrm{M}$ (for chicken). Thus, AThTP hydrolase has a quite high apparent affinity for substrate, like that of the specific soluble mammalian ThTPase $\left(K_{\mathrm{m}}=20-50 \mu \mathrm{M}\right.$ [23]). For comparison, the $K_{\mathrm{m}}$ values of non-specific phosphatases which might be involved in thiamine metabolism were reported to be $0.9 \mathrm{mM}$ for ThMPase from chicken liver [24], 17-20.7 mM for ThDPase (NDPase) from rat and bovine liver [19, 20], $2 \mathrm{mM}$ for ThDPase (NDPase) from rat brain [20], 1.5-2.2 $\mathrm{mM}$ for a membrane-associated ThTPase in various animal species [25-27].

AThTP hydrolase activity in animal tissues. The results of AThTP hydrolase assays in various bovine and chicken tissues are plotted in Fig. 6. As can be seen from the diagrams, the highest AThTP hydrolase content is inherent for liver and kidney of both animal species. Expressed in mU per mg protein, the specific AThTP hydrolase activity was distributed in bovine tissues as follows: kidney $(1.13 \pm 0.19)$ $>$ liver $(0.77 \pm 0.06)>$ spleen $(0.46 \pm 0.07) \approx$ brain $(0.42 \pm 0.03)>$ lung $(0.31 \pm 0.07)>$ heart $(0.24 \pm 0.05)$ $>$ skeletal muscle $(0.17 \pm 0.01)$. In chicken, the specific activity of the enzyme decreased in the next order $(\mathrm{mU} / \mathrm{mg}$ protein): liver $(0.674 \pm 0.187)>$ kidney $(0.296 \pm 0.066)>$ spleen $(0.093 \pm 0.009)>$ heart $(0.077 \pm 0.027)>$ lung $(0.055 \pm 0.013)>$ brain $(0.035 \pm 0.003)>$ skeletal muscle $(0.015 \pm 0.005)$. In rat liver and kidney, the enzyme activity amounts to $1.57 \pm 0.15$ and $0.99 \pm 0.41 \mathrm{mU} / \mathrm{mg}$ protein $(\mathrm{M} \pm \mathrm{SD}$, $n=3$, data not shown), correspondingly.

The tissue content of AThTP hydrolase seems to depend on animal age. At least, some kind of regularity can be traced in rat liver. As shown in Fig. 7, the liver of sucking rats (7-day old) contained the smallest amounts of enzyme activity. At the age of 1 to 3 months AThTP hydrolase activity was 3.2 times as high as that of suckers. A 1.7-fold decreasing of the rate of AThTP hydrolysis was observed in the liver homogenates of 7-month old animals as compared to 3 months aged, after that the enzyme activity was essentially unchangeable to deep old 

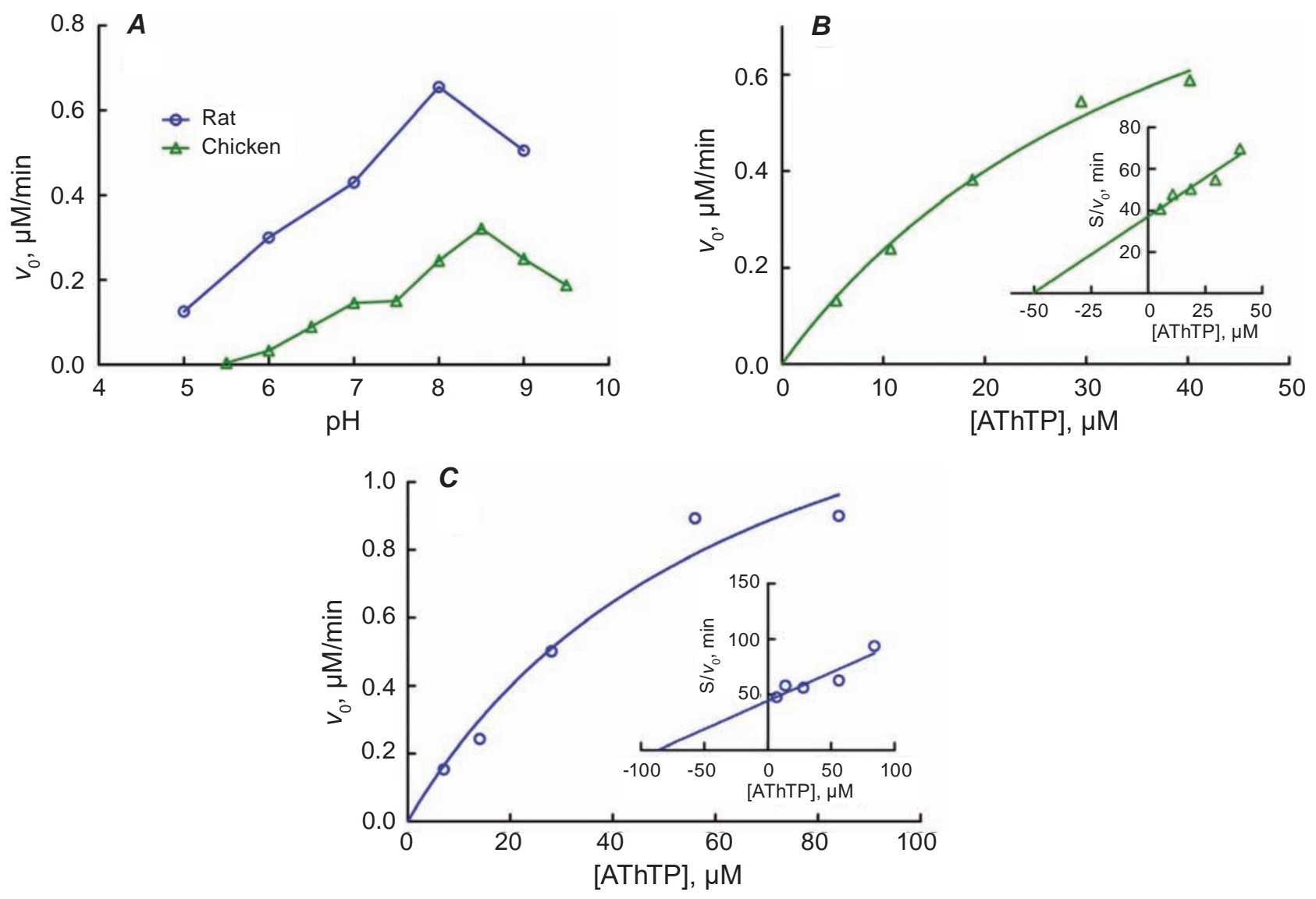

Fig. 5. Kinetic properties of rat and chicken liver AThTP hydrolase. (A) Effect of $p H$ on the initial rate of AThTP hydrolysis in chicken and rat liver homogenates. The buffers ( $25 \mathrm{mM}$ final concentration) used were: acetate ( $p H$ 5.0), Tris-maleate ( $p H$ 5.5-9.0), glycine ( $p H$ 9.5). The reaction was carried out for 10 min with $60 \mu \mathrm{g}$ of protein. The concentration of ThDP produced was determined by enzymatic procedure as described in Materials and Methods. (B) Effect of substrate concentration on the initial rate of AThTP hydrolysis in chicken liver homogenate at $p H$ 8.5. The reaction proceeded for 10 min with $120 \mu \mathrm{g}$ of protein. (C) Effect of substrate concentration on the initial rate of AThTP hydrolysis in rat liver homogenate at pH 8.0. The reaction time was $10 \mathrm{~min}$ with $60 \mu \mathrm{g}$ of protein in the reaction mixture. Insets: The Hanes plots of the data. Results of a representative experiment in each graph are shown

age (2.5 years). The significance of the differences was established by ANOVA ( $p=0.0004$ ) followed by Turkey's test for post hoc comparisons among the groups. It is worth mentioning the experimental groups were formed from rats which inhabited the institutional animal house simultaneously.

At present, no literature data are available on the biosynthesis of AThTP in animals. Yet, the extremely low activity of ThDP adenylyltransferase (EC 2.7.7.B3) in E. coli [8] and rat lung (unpublished data) implies the crucial tool to control the concentration of this compound in the cell might be the rate of its hydrolysis. The analysis of our data, however, indicate no correlation, either direct or inverse, to occur between the tissue AThTP content (Table 1) and AThTP hydrolase activity (Fig. 6). A possible reason of such a discrepancy could be the existence of kinetic regulatory mechanisms which are ceased due to the cell integrity disruption as well as dilution during homogenate preparing and enzyme assay.

In conclusion, our results suggest considerable differences, intra- and interspecies, in AThTP content as well as AThTP hydrolase activity in animal tissues. As regards to the enzymes catalyzing the hydrolysis of AThTP in rat and chicken liver, they resemble each other in having alkaline $\mathrm{pH}$ optima, similar values of $K_{\mathrm{m}}$, and also being metal-independent. This may imply their evolutional origin 

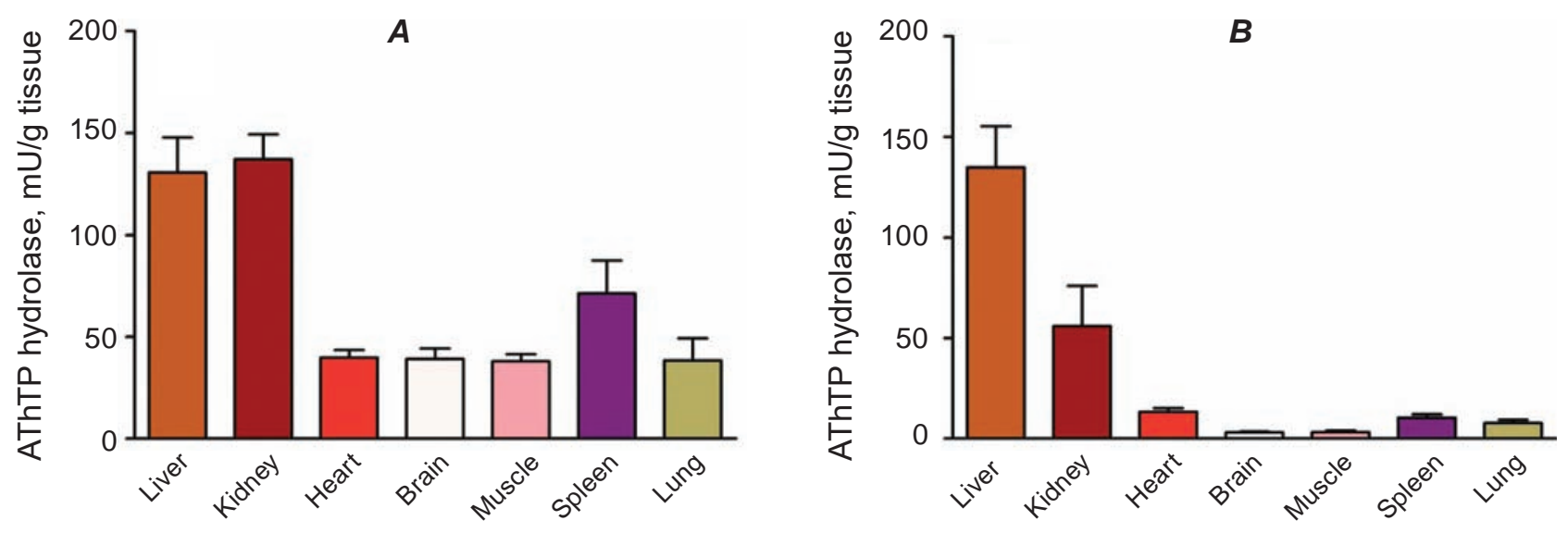

Fig. 6. Distribution of AThTP hydrolase activity in bovine $(\mathbf{A})$ and chicken $(\boldsymbol{B})$ tissues (means $\pm S D, n=3$ ). The amount of ThDP formed during AThTP hydrolysis at pH 8.0 was measured by enzymatic method using PDC as described in Materials and Methods

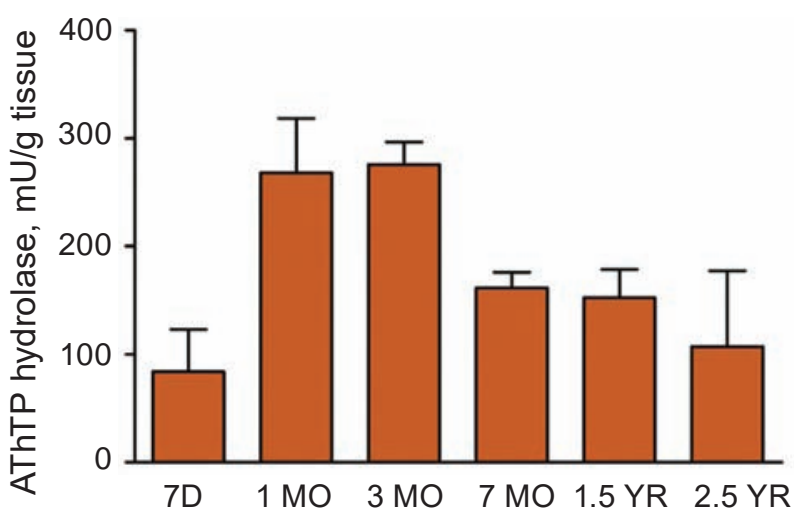

Fig. 7. Activity of AThTP hydrolase in rat liver in aging (means $\pm S D, n=3$ ). The amount of ThDP formed during AThTP hydrolysis at $\mathrm{pH} 8.0$ was measured by enzymatic method using PDC as described in Materials and Methods

from a common ancestor. The principle issue of question is the individuality of AThTP hydrolase, since the cell is known to expresses bis(5'-adenosyl)trpiphosphatase (Ap3Aase, EC 3.6.1.29) and unspecific phosphodiesterase I (PDEaseI, EC 3.1.4.1), both of which are potentially capable of AThTP hydrolyzing [28, 29]. While Ap3Aase, being a soluble $\mathrm{Mg}^{2+}$-dependent enzyme with both cytosolic and mitochondrial matrix location, could be probably excluded, two PDEaseI isozymes (NPP1 and NPP3) were shown to be localized in cellular plasma membrane [30]. Whether this ecto-nucleotidase is responsible for AThTP hydrolysis observed in animal tissues homogenates or a specific AThTP hydrolase exists is the matter of studies to come.

\section{АДЕНОЗИН-ТІАМІНТРИФОСФАТ І АКТИВНІСТЬ АДЕНОЗИН- ТІАМІНТРИФОСФАТГІДРОЛАЗИ В ТКАНИНАХ ТВАРИН}

O. Ф. Макарчиков ${ }^{1,2}$, T. В. Сорока Т. Г. Кудирко, ${ }^{1,2}$ I. К. Колос ${ }^{1,2}$, Т. О. Лучко I. М. Русина ${ }^{1,2}$, В. О. Гуринович ${ }^{2}$

${ }^{1}$ Гродненський державний аграрний університет, Білорусь;

${ }^{2}$ Інститут біохімії біологічно активних сполук НАН Білорусі;

${ }^{3}$ Гродненський державний університет імені Янки Купали, Білорусь;

e-mail: a_makarchikov@yahoo.com

Аденозин-тіамінтрифосфат (АТТФ) виявлено в різних біологічних об'єктах, включаючи бактерії, дріжджі, коріння рослин і тканини ссавців, проте біохімічні функції цього нуклеотиду невідомі. Мета цієї роботи полягала в дослідженні вмісту АТТФ і характеристиці властивостей ензиму, що каталізує його гідроліз в клітинах тварин. Показано, що АТТФ присутній в тканинах корів, щурів, мишей $\mathrm{i}$ курчат. У тварин гідроліз АТТФ здійснюється мембранно-асоційованим ензимом, який переважно локалізований в мікросомальній фракції клітини, виявляє максимальну активність при $\mathrm{pH} 8,0-8,5$ і не залежить від іонів $\mathrm{Mg}^{2+}$. Кінетика реакції, що каталізується АТТФ-гідролазою печінки щура і курчати, описується рівнянням Міхаеліса-Ментен, при цьому значення $K_{\mathrm{м}}$, розраховані в координатах Хейнса, станов- 
лять відповідно $84,4 \pm 9,4$ і 54,6 \pm 13,1 мкМ. Серед зразків тканин, що досліджувались найвищу АТТФ-гідролазну активність визначили в печінці і нирках. У печінці щурів швидкість гідролізу АТТФ залежила від віку тварин.

К л ю ч о в і сл о в а: вітамін $\mathrm{B}_{1}$, аденозинтіамінтрифосфат, аденозин-тіамінтрифосфатгідролаза, тканини тварин.

\section{АДЕНОЗИН-ТИАМИНТРИФОСФАТ И АКТИВНСТЬ АДЕНОЗИН- ТИАМИНТРИФОСФАТ- ГИДРОЛАЗЫ В ТКАНЯХ ЖИВОТНЫХ}

\section{А. Ф. Макарчиков ${ }^{1,2}$, Т. В. Сорока ${ }^{3}$, Т. Г. Кудырко ${ }^{1,2}$, И. К. Колос ${ }^{1,2}$, Т. А. Лучко ${ }^{2}$, И. М. Русина ${ }^{1,2}$, В. А. Гуринович ${ }^{2}$}

${ }^{1}$ Гродненский государственный аграрный университет, Беларусь; ${ }^{2}$ Институт биохимии биологически активных соединений НАН Беларуси;

${ }^{3}$ Гродненский государственный университет имени Янки Купалы, Беларусь; e-mail: a_makarchikov@yahoo.com

Аденозин-тиаминтрифосфат (АТТФ) обнаружен в различных биологических объектах, включая бактерии, дрожжи, корни растений и ткани млекопитающих, однако биохимические функции этого нуклеотида неизвестны. Цель данной работы заключалась в исследовании содержания АТТФ и характеристике свойств энзима, катализирующего его гидролиз в клетках животных. Показано, что АТТФ присутствует в тканях быка, крысы, мыши и цыпленка. У животных гидролиз АТТФ осуществляется мембранно-ассоциированным энзимом, который преимущественно локализован в микросомальной фракции клетки, проявляет максимальную активность при $\mathrm{pH} 8,0-8,5$ и не зависит от ионов $\mathrm{Mg}^{2+}$. Кинетика реакции, катализируемой АТТФгидролазой печени крысы и цыпленка описывается уравнением Михаэлиса-Ментен, при этом значения $K_{\mathrm{m}}$, рассчитанные в координатах Хейнса, составляют соответственно $84,4 \pm 9,4$ и $54,6 \pm 13,1$ мкМ. Среди образцов исследованных тканей самой высокой АТТФ-гидролазной активностью обладали печень и почки. В печени крыс скорость гидролиза АТТФ зависила от возраста животных.
Кл юче вы е слова: витамин $\mathrm{B}_{1}$, аденозин-тиаминтрифосфат, аденозин-тиаминтрифосфат-гидролаза, ткани животных.

\section{References}

1. Metzler DE. Biochemistry. The Chemical Reactions of Living Cells. Harcourt/Academic Press. 2nd ed. 2001, Vol 1, 937 p.

2. Zhao J, Zhong CJ. A review on research progress of transketolase. Neurosci Bull. 2009; 25(2): 9499.

3. Casteels M, Sniekers M, Fraccascia P, Mannaerts GP, Van Veldhoven PP. The role of 2-hydroxyacyl-CoA lyase, a thiamin pyrophosphate-dependent enzyme, in the peroxisomal metabolism of 3-methyl-branched fatty acids and 2-hydroxy straight-chain fatty acids. Biochem Soc Trans. 2007; 35(Pt 5): 876880.

4. Makarchikov AF. Vitamin $B_{1}$ : metabolism and functions. Biochemistry (Moscow) Suppl Ser B: Biomed Chem. 2009; 3(2): 116-128.

5. Bettendorff L, Wirtzfeld B, Makarchikov AF, Mazzucchelli G, Frédérich M, Gigliobianco T, Gangolf M, De Pauw E, Angenot L, Wins P. Discovery of a natural thiamine adenine nucleotide. Nat Chem Biol. 2007; 3(4): 211-212.

6. Gigliobianco T, Lakaye B, Wins P, El Moualij B, Zorzi W, Bettendorff L. Adenosine thiamine triphosphate accumulates in Escherichia coli cells in response to specific conditions of metabolic stress. BMC Microbiol. 2010; 10: 148.

7. Tanaka T, Yamamoto D, Sato T, Tanaka S, Usui K, Manabe M, Aoki Y, Iwashima Y, Saito Y, Mino Y, Deguchi H. Adenosine thiamine triphosphate (AThTP) inhibits poly(ADP-ribose) polymerase-1 (PARP-1) activity. J Nutr Sci Vitaminol (Tokyo). 2011; 57(2): 192-196.

8. Makarchikov AF, Brans A, Bettendorff L. Thiamine diphosphate adenylyl transferase from E. coli: functional characterization of the enzyme synthesizing adenosine thiamine triphosphate. BMC Biochem. 2007; 8: 17.

9. Chernikevich IP, Gritsenko EA, Makarchikov AF, Voskoboev AI. Fermentation micromethod for the quantitative determination of thiamine diphosphate in biological fluids. Prikl Biokhim Mikrobiol. 1991; 27(5): 762-771. (In Russian).

10. Bettendorff L, Peeters M, Jouan C, Wins P, Schoffeniels E. Determination of thiamin and its phosphate esters in cultured neurons and 
astrocytes using an ion-pair reversed-phase high-performance liquid chromatographic method. Anal Biochem. 1991; 198(1): 52-59.

11. Peterson GL. A simplification of the protein assay method of Lowry et al. which is more generally applicable. Anal Biochem. 1977; 83(2): 346-356.

12. Frédérich $M$, Delvaux $D$, Gigliobianco $T$, Gangolf M, Dive G, Mazzucchelli G, Elias B, De Pauw E, Angenot L, Wins P, Bettendorff L. Thiaminylated adenine nucleotides. Chemical synthesis, structural characterization and natural occurrence. FEBS J. 2009; 276(12): 3256-3268.

13. Gangolf $M$, Czerniecki J, Radermecker $M$, Detry O, Nisolle M, Jouan C, Martin D, Chantraine F, Lakaye B, Wins P, Grisar T, Bettendorff L. Thiamine status in humans and content of phosphorylated thiamine derivatives in biopsies and cultured cells. PLoS One. 2010; 5(10): e13616.

14. Parkhomenko YuM, Pavlova AS, Mejenskaya OA, Stepanenko SP, Chekhivska LI. Thiamine diphosphate synthesis and redox state indicator in rat brain during of $\mathrm{B}_{1}$ hypovitaminosis. $U \mathrm{kr}$ Biochem J. 2017; 89(5): 84-95.

15. Voskoboyev AI, Chernikeevich IP. Biosynthesis, degradation and transport of thiamine phosphoric esters. Minsk: Nauka and Tekhnika, 1987. 200 p. (In Russian).

16. Makarchikov AF, Chernikevich IP. Purification and characterization of thiamine triphosphatase from bovine brain. Biochim Biophys Acta. 1992; 1117(3): 326-332.

17. Ogawa K, Sakai M, Inomata K. Recent findings on ultracytochemistry of thiamin phosphatases. Ann N Y Acad Sci. 1982; 378(1): 188-214.

18. Makarchikov AF, Luchko TA, Rusina IM, Gulyai IE, Makar EA. Studies on enzymes of thiamine mono- and diphosphate hydrolysis in the membrane preparations from bovine tissues. Proc Natl Acad Sci Belarus, Biol Series. 2009; 2: 62-66. (In Russian).

19. Yamazaki M, Hayaishi O. Allosteric properties of nucleoside diphosphatase and its identity with thiamine pyrophosphatase. J Biol Chem. 1968; 243(11): 2934-2942.

20. Sano S, Matsuda Y, Miyamoto S, Nakagawa H. Thiamine pyrophosphatase and nucleoside diphosphatase in rat brain. Biochem Biophys Res Commun. 1984; 118(1): 292-298.
21. Eaton RH, Moss DW. Organic pyrophosphates as substrates for human alkaline phosphatases. Biochem J. 1967; 105(3): 1307-1312.

22. Stevens TJ, Arkin IT. Do more complex organisms have a greater proportion of membrane proteins in their genomes? Proteins. 2000; 39(4): 417-420.

23. Makarchikov AF, Lakaye B, Gulyai IE, Czerniecki J, Coumans B, Wins P, Grisar T, Bettendorff L. Thiamine triphosphate and thiamine triphosphatase activities: from bacteria to mammals. Cell Mol Life Sci. 2003; 60(7): 1477-1488.

24. Kolas IK, Makarchikov AF. Copurification of chicken liver soluble thiamine monophosphatase and low molecular weight acid phosphatase. $U k r$ Biochem J. 2017; 89(6): 13-21.

25. Barchi RL, Braun PE. A membrane-associated thiamine triphosphatase from rat brain. Properties of the enzyme. J Biol Chem. 1972; 247(23): 7668-7673.

26. Bettendorff L, Michel-Cahay C, Grandfils C, De Rycker C, Schoffeniels E. Thiamine triphosphate and membrane-associated thiamine phosphatases in the electric organ of Electrophorus electricus. J Neurochem. 1987; 49(2): 495-502.

27. Kolas IK, Makarchikov AF. Properties of chicken liver membrane-associated thiamine triphosphatase. Ukr Biochem J. 2015; 87(3): 3746. (In Russian).

28. Guranowski A, Wojdyła AM, PietrowskaBorek M, Bieganowski P, Khurs EN, Cliff MJ, Blackburn GM, Błaziak D, Stec WJ. Fhit proteins can also recognize substrates other than dinucleoside polyphosphates. FEBS Lett. 2008; 582(20): 3152-3158.

29. Cameselle JC, Costas MJ, Günther Sillero MA, Sillero A. Two low $K_{\mathrm{m}}$ hydrolytic activities on dinucleoside 5',5"'-P1,P4-tetraphosphates in rat liver. Characterization as the specific dinucleoside tetraphosphatase and a phosphodiesterase I-like enzyme. J Biol Chem. 1984; 259(5): 2879-2885.

30. Zimmermann H, Zebisch M, Sträter N. Cellular function and molecular structure of ectonucleotidases. Purinergic Signal. 2012; 8(3): 437-502.

Received 23.03.2018 